DOI: $10.26693 / \mathrm{jmbs} 06.03 .114$

UDC 611.81-091-008.9-092.18-055.62]-02:618.5-085.357:577.175.869]-092.9

Mamay I. Yu., Hryhorieva O. A., Dariy V. I.

\title{
Immunohistochemical Characteristics of Ischemic Process in Hippocampal Formation in Posterity of Female Rats after Labor Induction
}

\author{
Zaporizhzhia State Medical University, Ukraine
}

The response to perinatal hypoxia, developing in stimulating generic activity, is the activation of microglia, which induces the development of local inflammation of the brain and leads to the death of neurons. The formation of the hippocampus supports important physiological and behavioral functions, including spatial learning and memory, and is part of the brain, which is especially vulnerable to changes in blood glucose and oxygen. Thus, the study of the features of the development of hippocampal formation in the postnatal period after stimulating generic activity is relevant.

The purpose of the study was to study the features of Glial fibrillary acidic protein and NeuN expression in the hippocampal formation in posterity of female rats after PgE2 injection for labor induction.

Materials and methods. Pregnant females of the experimental group on the twenty-second day of pregnancy were injected intravaginally with PGE2 in the form of a gel to stimulate the generic activity. Birth occurred on the twenty-third day after conception. Birth in the intact group of rats occurred on the 23-24 $4^{\text {th }}$ day after conception. The large hemispheres of the rat brain were fixed in a $10 \%$ neutral formal solution, dehydrated in an ascending alcohol battery. For immunohistochemical studies, paraffin sections were used with 3 microns with a thickness of $3 \mathrm{mi}-$ crons. Glial fibrillary acidic protein Mouse Monoclonal Antibody (Santa Cruz Biotechnology, Inc.) is used to detect astrocytes (Santa Cruz Biotechnology, Inc.). NeuN Mouse Monoclonal Antibody (Santa Cruz Biotechnology, Inc.) was used to identify neurons on the $1^{\text {st }}, 7^{\text {th }}, 14^{\text {th }}, 45^{\text {th }}$ days after birth in histological cuts of hippocampus and gear, using a program for analyzing and processing images Image $\mathrm{J}$, studied the relative area occupied by Glial fibrillary acidic protein $+\mathrm{NeuN}$ + cells. Data is processed by variation statistics. The results are reliable at $p<0.05$.

All animal experiments were performed according to international principles of the European Convention for the Protection of Vertebrate Animals Used for Experimental and Other Scientific Purposes" (Strasbourg, 18.03.86) and the Law of Ukraine No. 1759-VI (15.12.2009) On the Protection of Animals from Cruelty.

Results and discussion. We identified that by the changes in the hippocampus and the toothed gyrus of the rats after induction of labor, increased Glial fibrillary acidic protein expression on the first day after birth and reducing the NeuN expression on the $14^{\text {th }}$ and $45^{\text {th }}$ day of life in experimental animals compared to the control group were included.

Conclusion. The density of the distribution of Glial fibrillary acidic protein + cells in the hippocampus and the dentate gyrus of rats changes wavily throughout the first month and a half of postnatal life. In the offspring of rats, after stimulation of labor on the first day of life, a reliable increase in the relative area occupied by Glial fibrillary acidic protein + astrocytes is determined compared to the control $(49.3 \pm 2.6 \%$ and $36.8 \pm 5.9 \%$, respectively). In the hippocampus and the dentate gyrus of rats after stimulation of labor during the first 45 days after birth, the gradual decrease in the relative area occupied by NeuN + neurons is determined, in contrast to the control animals, in which this index practically does not change. On the $14^{\text {th }}$ and $45^{\text {th }}$ days, the index of the relative area occupied by $\mathrm{NeuN}+$ neurons in experimental rats is reliably lower than in control $(p<0.05)$.

Keywords: labor stimulation, hippocampus, dentate gyrus, Glial fibrillary acidic protein, NeuN.

Connection of work with scientific programs, plans, themes. This article is a fragment of scientific research work "Features of structures of rats after the action of factors of different nature in the pre- and postnatal period", state registration No 0120 U103118.

Introduction. Labor induction is one of the most frequently performed obstetric procedures in the world: the latest data for the percentage of induced labor are up to $35.5 \%$ in Sri Lanka, $24.5 \%$ in the USA and up to $33 \%$ in Europe [1]. Compared with placebo, the use of vaginal and cervical prostaglandin E2 is associated with an increased risk of uterine hyperstimulation with or without changes in fetal heart rate [2].

During stimulated labor, the fetus may experience cerebral hypoxia-ischemia, which can cause severe brain damage and subsequent long-term functional impairment [3]. The response to perinatal hypoxia is the activation of microglia, which induces the development of local inflammation of the brain and leads to the death of neurons [4]. Perinatal hypoxia caused by ischemia can cause damage to the central gray matter, which is associated with an increase in mortality 
in the neonatal period (20-30\%) and an increased risk of speech and communication disorders, the development of epilepsy and cerebral palsy in the future [5]. Ischemic conditions of the brain in the neonatal period can lead to cognitive deficits, which are similar to some phenotypes observed in children with neurological disorders [6]. W. Froehlich-Santino et al. (2014), analyzing data from medical records, found that prenatal or perinatal hypoxia increases the risk of developing disorders of hyperactivity, attention deficit and correlates with impaired behavior and communication in childhood [7]. The formation of the hippocampus supports important physiological and behavioral functions, including spatial learning and memory, and is the part of the brain that is particularly vulnerable to changes in blood glucose and oxygen levels [8].

Glial fibrillary acidic protein (GFAP) is widely used as a reliable biomarker for detecting and assessing the severity of ischemic brain damage and astrogliosis developing against this background [9]. NeuN staining reflects the degree of neuronal loss in the brain after decreased oxygenation, which promotes ischemic damage, irreversible secondary brain damage that leads to apoptosis and decreased cellularity [10].

Thus, it is important to study the immunohistochemical features of the hippocampal formation in posterity of female rats after PgE2 injection for labor induction.

The purpose of the study is to study the features of GFAP and NeuN expression in the hippocampal formation in posterity of female rats after PgE2 injection for labor induction.

Materials and methods. The beginning of pregnancy was established using the method of vaginal smears stained with methylene blue; the presence of sperm in smears was the evidence of the 0 day of pregnancy. Pregnant females of the experimental group were injected PgE2 in the form of a gel intravaginally to stimulate labor on the $22^{\text {nd }}$ day of pregnancy. The duration of the experimental rats pregnancy amounted to 23 days, in the intact group 23-24 days after conceiving.

We were guided by the "European Convention for Working with Experimental Animals". Animals were contained in standard conditions of vivarium according to "European Convention for the Protection of Vertebrate Animals Used for Experimental and Other Scientific Purposes" (Strasbourg, 18.03.86) and the Law of Ukraine No. 1759-VI (15.12.2009) On the Protection of Animals from Cruelty. Food and water were made available ad libitum.

The cerebral hemispheres of rats were fixed in a $10 \%$ solution of neutral formalin and dehydrated in an ascending battery of ethyl spirits. $3 \mu \mathrm{m}$ thick paraffin sections were used for immunohistochemical studies.
Dewaxing, rehydration, and antigen unmasking were performed by heating in citrate buffer $\mathrm{pH} 6.0$ using a PT module Thermo Fisher Scientific. Endogenous peroxidase was blocked using a $3 \%$ hydrogen peroxide solution. After conditioning with Ultra V Block, incubation with antibodies was produced following the instructions of the antibody manufacturer. Visualization was performed using the UltraVision Quanto HRP + DAB System, followed by additional staining with Mayer's hematoxylin, dehydration, clarification, and contraction in a balm. GFAP (2E1) sc-33673 mouse monoclonal antibody (Santa Cruz Biotechnology, Inc.) was used to detect astrocytes, and NeuN (0.N.211) sc-71667 mouse monoclonal antibody (Santa Cruz Biotechnology, Inc.) was used to detect neurons. In histological samples, we studied the relative area expressing GFAP, NeuN in the hippocampus and dentate gyrus of the animals brain in experimental and control groups on the $1^{\text {st }}, 7^{\text {th }}, 14^{\text {th }}, 45^{\text {th }}$ days after birth, using the program for the analysis and processing of images ImageJ. Photos of histological samples were conducted using CarlZeiss software (AxioVision 4.8).

Analysis of the obtained results was conducted by means of statistical methods with the use of computer license program «Statistica for Windows 13» (StatSoft Inc., No. JPZ804I382130ARCN10-J). The significance of the differences between the experimental groups was assessed using the Student's criterion $t$, considering the differences to be reliable at $p<0.05$, that is generally accepted for biological and medical researches. The numerical data of the obtained results are presented as $\mathrm{M} \pm \mathrm{m}$ (arithmetic mean \pm standard error of the mean).

Research results. It was revealed that GFAP + cells in the hippocampus are evenly located in the astrocytes CA1, CA2, CA3 fields of the hippocampus and dentate gyrus. On the $1^{\text {st }}$ day of life in rats of the experimental group, there is a significant increase in immunopositivity to GFAP compared to the control group: in percentage terms, the area marked with specific antibodies was $49.3 \pm 2.6 \%$ in the experimental group (Fig. 1), $36.8 \pm 5.9 \%$ in the control group of animals. At the same time, in the experimental group of animals, astrocytes became noticeably larger with an increase of the soma size and thickening of the processes.

On the $7^{\text {th }}$ day of life, the area with the detected expression of glial acidic fibrillar protein was $31.7 \pm 5.9 \%$ in experimental and $29.9 \pm 1.9 \%$ in control groups; on the $14^{\text {th }}-32.3 \pm 2.5 \%$ in experimental, $30.8 \pm 4.1 \%$ in control; on the $45^{\text {th }}-37.3 \pm 2.7 \%, 37.4 \pm 2.5 \%$ in the experimental and control groups, respectively.

NeuN showed staining of neurons in all layers of CA1, CA2, CA3 fields of the hippocampus and dentate gyrus. NeuN + hippocampal cells are characterized by the arrangement of $\mathrm{NeuN}$ in and around the nucleus. 


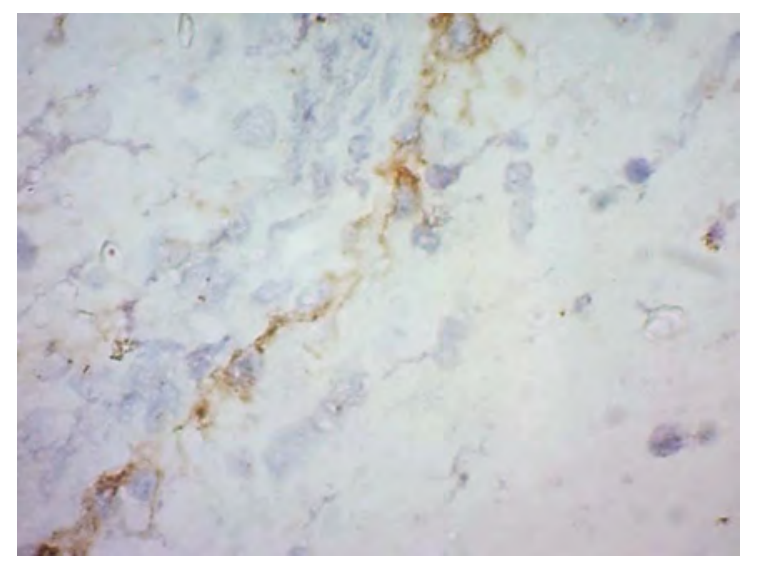

Figure 1. CA2 field of the hippocampus of the experimental group on the $1^{\text {st }}$ day of life. GFAP, hematoxylin. Magnification $\times 1000$

There is a tendency to decreasing in the area covered by mature neurons in the experimental group compared to the control group of animals: in the experimental group, the percentage of the area marked with NeuN was $42 \pm 2.1 \%$ on the $1^{\text {st }}$ day of life, $39 \pm 1.4 \%$ on $7^{\text {th }}$ day, $31.6 \pm 2.91 \%$ on the $14^{\text {th }}$ day and $31.9 \pm 1.8 \%$ on the $45^{\text {th }}$ day after birth. The degree of expression of the neuronal nuclear antigen NeuN in the control group of animals as a percentage was $42.3 \pm 3.3 \%$ on the $1^{\text {st }}$ day after birth, $39.1 \pm 1.6 \%$ - on the $7^{\text {th }}$ day, $40.4 \pm 3.5 \%$ - on the $14^{\text {th }}$ day and $41.4 \pm 2.7 \%$ - on the $45^{\text {th }}$ day of life (Table 1).

Table 1 - Characterization of the expression of GFAP, NeuN in the rats' hippocampus and dentate gyrus in the postnatal period $(\mathrm{M} \pm \mathrm{m}, \%)$

\begin{tabular}{|c|c|c|c|c|}
\hline \multirow{2}{*}{$\begin{array}{c}\text { Day } \\
\text { of life }\end{array}$} & \multicolumn{2}{|c|}{ GFAP, \% } & \multicolumn{2}{c|}{ NeuN, \% } \\
\cline { 2 - 5 } & $\mathbf{1}$ & $\mathbf{2}$ & $\mathbf{1}$ & $\mathbf{2}$ \\
\hline 1 & $36.8 \pm 5.9$ & $49.3 \pm 2.6^{*}$ & $42.3 \pm 3.3$ & $42 \pm 2.1$ \\
\hline 7 & $29.9 \pm 1.9$ & $31.7 \pm 5.9$ & $39.1 \pm 1.6$ & $39 \pm 1.4$ \\
\hline 14 & $30.8 \pm 4.1$ & $32.3 \pm 2.5$ & $40.4 \pm 3.5$ & $31.6 \pm 2.91^{*}$ \\
\hline 45 & $37.4 \pm 2.5$ & $37.3 \pm 2.7$ & $41.4 \pm 2.7$ & $31.9 \pm 1.8^{*}$ \\
\hline
\end{tabular}

Notes: 1 - intact group of rats, 2 - experimental group of rats

Discussion. Guang Yang et al. (2015) showed that in the brain of the offspring of experimental animals that received PgE2 during pregnancy, structural changes corresponding to ischemic-hypoxic brain damage were revealed [11]. We have previously identified changes in the structure of the cerebellar cortex and ultrastructural changes in the hippocampal formation in the posterity of rats after intravaginal injection of PgE2, which may indicate hypoxia of the brain tissue [12].

The mechanisms of damage are probably caused by perinatal hypoxia of the fetal brain, due to hyperstimulation and changes in fetal heart rate [13]. Under the conditions of these mechanisms, the structures of the brain that are sensitive to hypoxia are damaged first of all. In the subgranular zone of the dentate gyrus of the adult hippocampus, one of two neurogenic niches in the adult mammalian brain, new neurons are constantly generated throughout adult life. Most of neonatal cells in the hippocampus die during early differentiation from intermediate progenitors to immature neurons [14].

The study by M. D. Wilson (2015) revealed a significant damage in the structure of the hippocampus after hypoxic brain injury in a newborn [15]. The results of studies by Javad Hami et al. (2015) showed that changes in blood glucose and oxygen levels can reduce the number of pyramidal cells in the hippocampus of newborn rats, especially in the CA3 region [8].

In a separate model of hypoxia-ischemia, including a period of oxygen-glucose deprivation and subsequent reoxygenation, D. K. Grosenbaugh et al. (2018) observed a significant increase of excitatory neurotransmission in the pyramidal cells of the CA3 region of hippocampus, which the authors associate with the development of seizures in the neonatal period [16].

The changes in the hippocampus and dentate gyrus of rat offspring after labor induction that we identified include an increase of GFAP expression on the first day after birth and a decrease of NeuN expression on days 14 and 45 of life in experimental animals compared to the control group.

The degree of GFAP expression reflects the functional state of astrocytes, their growth and division [17]. The increased expression of GFAP in astrocytes is proportional to the degree of reactivity. Mild to moderate reactive astrogliosis is usually associated with mild non-penetrating and non-contusional trauma, with diffuse activation of innate immunity, or with areas that are at some distance from focal CNS lesions [18].

The study by Jinxin Wang et al. showed that the number of GFAP-positive cells increased in the brain of rats in the group of experimental animals which was held bilateral stenosis of the common carotid artery, and this phenomenon was even more expressed in the group of experimental animals which was held bilateral occlusion of the common carotid artery [19].

NeuN is an intracellular marker of neuronal cells [20]. In a study by V. Ilievski et al. (2018), the integrity of hippocampal and dentate gyrus neurons after inflammation was determined using the NeuN antibody, which detects intact neurons. The difference between the number of NeuN-positive cells between the control and experimental groups was statistically significant in the dentate gyrus and CA1 areas [21]. Several studies have revealed similar changes in the decrease of NeuN expression in the hippocampus and dentate gyrus against the background of chronic 
hypoxic conditions [22, 23]. Similar results were found by a number of other researchers during analyzing the structure of the hippocampus after hypoxic-ischemic conditions in the neonatal period [24, 25].

\section{Conclusion}

1. The density of the distribution of GFAP + cells in the hippocampus and the dentate gyrus of rats changes wavily throughout a month and a half of postnatal life. In the offspring of rats, after stimulation of labor on the first day of life, a reliable increase in the relative area occupied by GFAP + astrocytes is determined compared to the control $(49.3 \pm 2.6 \%$ and $36.8 \pm 5.9 \%$, respectively).
2. In the hippocampus and the dentate gyrus of rats after stimulation of labor throughout the first 45 days after birth, the gradual decrease in the relative area occupied by NeuN + neurons is determined, in contrast to the control animals, in which this index practically does not change. On the $14^{\text {th }}$ and $45^{\text {th }}$ day of life, the index of the relative area occupied by NeuN + neurons in experimental rats is reliably lower than in control $(p<0.05)$.

Prospects for further research. Ultrastructural peculiarities of hippocampus and dentate gyrus reactivity in rats' offspring after labor stimulation of pregnant female rats will be studied later on.

\section{References}

1. Marconi AM. Recent advances in the induction of labor. Review F1000Res. 2019 Oct 30; 8: F1000 Faculty Rev1829. doi: $10.12688 / f 1000$ research. 17587.1

2. Mozurkewich EL, Chilimigras JL, Berman DR, Perni UC, Romero VC, King VJ, et al. Methods of induction of labour: a systematic review. Review BMC Pregnancy Childbirth. 2011; 11: 84. doi: 10.1186/1471-2393-11-84

3. Markus T, Ley D, Hansson SR, Wieloch T, Ruscher K. Neuroprotective dobutamine treatment upregulates superoxide dismutase 3 , anti-oxidant and survival genes and attenuates genes mediating inflammation. BMC Neurosci. 2018; 19(1): 9. doi: 10.1186/s12868-018-0415-2

4. Morales P, Bustamnte D, Espna-Marchant P. Pathophysiology of perinatal asphyxia: can we predict and improve individual outcomes? EPMA J. 2011; 2(2): 211-230. doi: 10.1007/s13167-011-0100-3

5. Martinez-Biarge M, Diez-Sebastian J, Rutherford MA. Outcomes after central grey matter injury in term perinatal hypoxic-ischaemic encephalopathy. Early Hum Dev. 2010; 86(11): 675-82. doi: 10.1016/j.earlhumdev.2010.08.013

6. Yu HL, Wang LZ, Zhang LL, Chen BL, Zhang HJ, Li YP, et al. ESE1 expression correlates with neuronal apoptosis in the hippocampus after cerebral ischemia/reperfusion injury. Neural Regen Res. 2019; 14(5): 841-849. doi: 10.4103/1673-5374.249232

7. Froehlich-Santino W, Londono Tobon A, Cleveland S, Torres A, Phillips J, Cohen B, et al. Prenatal and perinatal risk factors in a twin study of autism spectrum disorders. J Psychiatr Res. 2014; 54: 100-8. doi: 10.1016/j.jpsychires.2014.03.019

8. Hami J, Shojae F, Vafaee-Nezhad S, Lotfi N, Kheradmand H, Haghir H. Some of the experimental and clinical aspects of the effects of the maternal diabetes on developing hippocampus. Review World J Diabetes. 2015; 6(3): 412-22. doi: 10.4239/wjd.v6.i3.412

9. Goffigan-Holmes J, Sanabria D, Diaz J, Flock D, Chavez-Valdez R. Calbindin-1 Expression in the Hippocampus following Neonatal Hypoxia-Ischemia and Therapeutic Hypothermia and Deficits in Spatial Memory. Dev Neurosci. 2019; 5-6: 1-15. doi: 10.1159/000497056

10. Thelin EP, Frostell A, Mulder J, Mitsios N, Damberg P, Aski SN, et al. Lesion Size Is Exacerbated in Hypoxic Rats Whereas Hypoxia-Inducible Factor-1 Alpha and Vascular Endothelial Growth Factor Increase in Injured Normoxic Rats: A Prospective Cohort Study of Secondary Hypoxia in Focal Traumatic Brain Injury. Front Neurol. 2016; 7: 23. doi: 10.3389/fneur.2016.00023

11. Yang G, Dong WH, Hu CL, Mei YA. PGE2 Modulates GABAA Receptors via an EP1 Receptor-Mediated Signaling Pathway. Cell Physiol Biochem. 2015; 36(5): 1699-711. doi: 10.1159/000430143

12. Hrygorieva EA, Mamay IY. Hippocampus and dentate gyrus morphological changes in posterity of female rats after receiving PgE2 for labor induction. Morphologia. 2019; 13(4): 10-5. doi: 10.26641/1997-9665.2019.4.10-15

13. Gommers JS, Diederen M, Wilkinson C. Risk of maternal, fetal and neonatal complications associated with the use of the transcervical balloon catheter in induction of labour: A systematic review. Eur J Obstet Gynecol Reprod Biol. 2017; 218: 73-84. doi: 10.1016/j.ejogrb.2017.09.014

14. Chatzi C, Schnell E, Westbrook GL. Localized hypoxia within the subgranular zone determines the early survival of newborn hippocampal granule cells. Elife. 2015; 4: e08722. doi: 10.7554/eLife.08722

15. Wilson MD. Animal Models of Cerebral Palsy: Hypoxic Brain Injury in the Newborn. Iran J Child Neurol. 2015; 9(2): 9-16.

16. Grosenbaugh DK, Ross BM, Wagley P, Zanelli SA. The Role of Kainate Receptors in the Pathophysiology of Hypoxia-Induced Seizures in the Neonatal Mouse. Sci Rep. 2018; 8(1): 7035. doi: 10.1038/s41598-018-24722-3 
17. Hol EM, Pekny M. Glial fibrillary acidic protein (GFAP) and the astrocyte intermediate filament system in diseases of the central nervous system. Curr Opin Cell Biol. 2015; 32: 121-130.

18. Zamanian JL, Xu L, Foo LC, Nouri N, Zhou L, Giffard RG, et al. Genomic analysis of reactive astrogliosis. $J$ Neurosci. 2012; 32: 6391-6410.

19. Wang J, Yang C, Wang H, Li D, Li T, Sun Y, et al. New Rat Model of Chronic Cerebral Hypoperfusion Resulting in Early-Stage Vascular Cognitive Impairment. Front Aging Neurosci. 2020; 12: 86. doi: 10.3389/fnagi.2020.00086

20. Rubio FJ, Li X, Liu QR, Cimbro R, Hope BT. Fluorescence Activated Cell Sorting (FACS) and Gene Expression Analysis of Fos-expressing Neurons from Fresh and Frozen Rat Brain Tissue. J Vis Exp. 2016; 114: 54358. doi: $10.3791 / 54358$

21. Ilievski V, Zuchowska PK, Green SJ, Toth PT, Ragozzino ME, Le K, et al. Chronic oral application of a periodontal pathogen results in brain inflammation, neurodegeneration and amyloid beta production in wild type mice. PLoS One. 2018; 13(10): e0204941. doi: 10.1371/journal.pone.0204941

22. Kim MS, Choi BR, Lee YW, Kim DH, Han YS, Jeon WK, et al. Chronic Cerebral Hypoperfusion Induces Alterations of Matrix Metalloproteinase-9 and Angiopoietin-2 Levels in the Rat Hippocampus. Exp Neurobiol. 2018; 4: 299-308. doi: 10.5607/en.2018.27.4.299

23. Ma H, Lam PK, Wai Tong CS, Yan Lo KK, Chu Wong GK, Poon WS. The neuroprotection of hypoxic adipose tissue-derived mesenchymal stem cells in experimental traumatic brain injury. Cell Transplant. 2019; 28(7): 874884. doi: 10.1177/0963689719855624

24. Jantzie LL, Getsy PM, Denson JL, Firl DJ, Maxwell JR, Rogers DA, et al. Prenatal Hypoxia-Ischemia Induces Abnormalities in CA3 Microstructure, Potassium Chloride Co-Transporter 2 Expression and Inhibitory Tone. Front Cell Neurosci. 2015; 9: 347. doi: 10.3389/fncel.2015.00347

25. Sun Y, Zhang Y, Wang X, Blomgren K, Zhu C. Apoptosis-inducing factor downregulation increased neuronal progenitor, but not stem cell, survival in the neonatal hippocampus after cerebral hypoxia-ischemia. Mol Neurodegener. 2012 Apr 25; 7: 17. doi: 10.1186/1750-1326-7-17

\section{УДК 611.81-091-008.9-092.18-055.62]-02:618.5-085.357:577.175.869]-092.9 \\ ІМУНОГІСТОХІМІЧНА ХАРАКТЕРИСТИКА ІШЕМІЧНИХ ПРОЦЕСІВ \\ В ГІПОКАМПІ ТА ЗУБЧАСТІЙ ЗВИВИНІ ГОЛОВНОГО МОЗКУ ПОТОМСТВА ЩУРІВ ПІСЛЯ СТИМУЛЯЦії ПОЛОГІВ \\ Мамай І. Ю., Григор'єеа О. А., Дарій В. І.}

Резюме. Вивчення особливостей розвитку гиппокампальної формації в постнатальному періоді після стимуляції родової діяльності є актуальним.

Meта. Вивчити особливості експресії GFAP і NeuN в гиппокампальної формації потомства щурів після інтравагінального введення PgE2 самкам для стимуляції родової діяльності.

Матеріали та методи. Вагітним самкам експериментальної групи на 22й день вагітності для стимуляції родової діяльності вагінально вводили PgE2 у вигляді гелю. Великі півкулі головного мозку щурів фріксували в 10\% розчині нейтрального формаліну, зневоднювали у висхідній батареї спиртів. Для виявлення астроцитів використовували GFAP mouse monoclonal antibody (Santa Cruz Biotechnology, inc.). Для виявлення нейронів використовували NeuN mouse monoclonal antibody (Santa Cruz Biotechnology, inc.). В гістологічних зрізах вивчали відносну площу, займану GFAP + i NeuN + клітинами. Дані оброблені методом варіаційної статистики. Результати достовірні при $p<0,05$.

Утримання тварин та експерименти проводилися за міжнародними принципами Європейської конвенції про захист тварин, що використовуються для експериментальних та інших наукових цілей (Страсбург, 18.03.86) та Закону України № 1759-VI (15.12.2009) «Про захист тварин від жорстокого поводження».

Результати. Щільність розподілу GFAP + клітин в гіпокампі і зубчастої звивини щурів хвилеподібно змінюється протягом перших півтора місяців постнатального життя. У потомства щурів після стимуляції родової діяльності на першу добу життя визначається достовірне збільшення відносної площі займаної

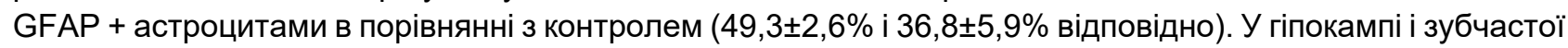
звивини потомства щурів після стимуляції родової діяльності протягом перших 45-ти діб після народження визначається поступове зменшення відносної площі, займаної NeuN + нейронами на відміну від контрольних тварин, у яких цей показник практично не змінюється.

Ключові слова: стимуляція пологів, гіпокамп, зубчаста звивина, GFAP, NeuN. 
Удк 611.81-091-008.9-092.18-055.62]-02:618.5-085.357:577.175.869]-092.9

ИММУНОГИСТОХИМИЧЕСКАЯ ХАРАКТЕРИСТИКА ИШЕМИЧЕСКИХ ПРОЦЕССОВ В ГИППОКАМПЕ И ЗУБЧАТОЙ ИЗВИЛИНЕ ГОЛОВНОГО МОЗГА ПОТОМСТВА КРЫС ПОСЛЕ СТИМУЛЯЦИИ РОДОВ

Мамай И. Ю., Григорьева О. А., Дарий В. И.

Резюме. Изучение особенностей развития гиппокампальной формации в постнатальном периоде после стимуляции родовой деятельности является актуальным.

Цель. Изучить особенности экспрессии GFAP и NeuN в гиппокампальной фрормации потомства крыс после интравагинального введения $\mathrm{PgE} 2$ самкам для стимуляции родовой деятельности.

Материалы и методы. Беременным самкам экспериментальной группы на двадцать второй день беременности для стимуляции родовой деятельности интравагинально вводили PgE2 в виде геля. Большие полушария головного мозга крыс фиксировали в 10\% растворе нейтрального формалина, обезвоживали в восходящей батарее спиртов. Для выявления астроцитов использовали GFAP mouse monoclonal antibody (Santa Cruz Biotechnology, inc.), для выявления нейронов использовали NeuN mouse monoclonal antibody (Santa Cruz Biotechnology, inc.). В гистологических срезах гиппокампа и зубчатой извилины крыс изучали относительную площадь, занимаемую GFAP+ и NeuN+ клетками. Данные обработаны методом вариационной статистики. Результаты достоверны при $p<0,05$.

Содержание животных и эксперименты проводились согласно международным принципам Европейской конвенции о защите животных, используемых для экспериментальных и других научных целей (Страсбург, 18.03.86) и Закона Украины № 1759-VI (15.12.2009) «О защите животных от жестокого обращения».

Результаты. Плотность распределения $\mathrm{GFAP}^{+}$клеток в гиппокампе и зубчатой извилине крыс волнообразно изменяется на протяжении первых полутора месяцев постнатальной жизни. У потомства крыс после стимуляции родовой деятельности на первые сутки жизни определяется достоверное увеличение относительной площади занимаемой GFAP ${ }^{+}$астроцитами по сравнению с контролем (49,3 $\pm 2,6 \%$ и $36,8 \pm 5,9 \%$ соответственно). В гиппокампе и зубчатой извилине потомства крыс после стимуляции родовой деятельности на протяжении первых 45-ти суток после рождения определяется постепенное уменьшение относительной площади, занимаемой $\mathrm{NeuN}^{+}$нейронами в отличие от контрольных животных, у которых этот показатель практически не изменяется.

Ключевые слова: стимуляция родов, гиппокамп, зубчатая извилина, GFAP, NeuN.

\section{ORCID and contributionship:}

Iryna Yu. Mamay: 0000-0002-1437-8106 B, C, D

Olena A. Hryhorieva: 0000-0002-6101-8322 A, D, E, F

Volodymyr I. Dariy: 0000-0001-9074-6911 E,F

A - Work concept and design, B - Data collection and analysis,

C - Responsibility for statistical analysis, D - Writing the article,

E - Critical review, F - Final approval of the article

\section{CORRESPONDING AUTHOR}

Olena A. Hryhorieva

Zaporizhzhia State Medical University,

Human anatomy department

24, Mayakovsky Ave., Zaporizhzhia 69035, Ukraine

tel. +380505450471, e-mail: elengrig212@gmail.com

The authors of this study confirm that the research and publication of the results were not associated with any conflicts regarding commercial or financial relations, relations with organizations and/or individuals who may have been related to the study, and interrelations of coauthors of the article.

Received: 15.03 .2021 p.

Рекомендована до друку на засіданні редакційної колеаії після рецензування 